\title{
Review of ozone and temperature lidar validations performed within the framework of the Network for the Detection of Stratospheric Change
}

\author{
Philippe Keckhut, ${ }^{a}$ Stuart McDermid,${ }^{b}$ Daan Swart, ${ }^{c}$ Thomas McGee, ${ }^{d}$ \\ Sophie Godin-Beekmann, ${ }^{a}$ Alberto Adriani, ${ }^{e}$ John Barnes, ${ }^{f}$ Jean-Luc Baray, ${ }^{g}$ \\ Hassan Bencherif, ${ }^{g}$ Hans Claude, ${ }^{h}$ Aleide G. di Sarra, ${ }^{i}$ Georgio Fiocco,,${ }^{i}$ Georg Hansen,${ }^{j}$ \\ Alain Hauchecorne, ${ }^{a}$ Thierry Leblanc, ${ }^{b}$ Choo Hie Lee, ${ }^{k}$ Shiv Pal, ${ }^{l}$ Gerard Megie, ${ }^{a}$ \\ Hideaki Nakane, ${ }^{m}$ Roland Neuber, ${ }^{n}$ Wolfgang Steinbrecht ${ }^{h}$ and Jeffrey Thayer ${ }^{o}$
}

\author{
${ }^{a}$ Service d'Aéronomie/IPSL, Verrière-le-Buisson, France \\ ${ }^{b}$ Table Mountain Facility, Jet Propulsion Laboratory, Wrightwood, CA, USA \\ ${ }^{c}$ National Institute for Public Health and the Environment, Bilthoven, The Netherlands \\ ${ }^{d}$ Laboratory for Atmospheres, Goddard Space Flight Center, Greenbelt, MD, USA \\ 'Istituto Fisica dell'Atmosfera, CNR, Rome, Italy \\ ${ }^{f}$ National Oceanic and Atmospheric Administration, Mauna Loa Observatory, Hilo, HI, USA \\ ${ }^{g}$ Laboratoire de Physique de l'Atmosphère, Université de La Réunion, St-Denis, France \\ ${ }^{h}$ Meteorologisches Observatorium Hohenpeissenberg, Hohenpeissenberg, Germany \\ ${ }^{i}$ Universita La Sapienza, Dipartemento di Fissica, Roma, Italy \\ ${ }^{j}$ Norwegian Institute for Air Research, Kjeller, Norway \\ ${ }^{k}$ Lidar Center of Kyung Hee University, Gyeonggi-Do, South Korea \\ ${ }^{l}$ Science And Art Innovation Inc., Ontario, Canada \\ ${ }^{m}$ National Institute for Environmental Studies, Tsukuba, Japan \\ ${ }^{n}$ Alfred Wegener Institute, Potsdam, Germany \\ ${ }^{o}$ SRI International Center for Geospace Studies, Menlo Park, CA, USA
}

Received 15th April 2004, Accepted 1st June 2004

First published as an Advance Article on the web 26th July 2004

\begin{abstract}
The use of assimilation tools for satellite validation requires true estimates of the accuracy of the reference data. Since its inception, the Network for Detection of Stratospheric Change (NDSC) has provided systematic lidar measurements of ozone and temperature at several places around the world that are well adapted for satellite validations. Regular exercises have been organised to ensure the data quality at each individual site. These exercises can be separated into three categories: large scale intercomparisons using multiple instruments, including a mobile lidar; using satellite observations as a geographic transfer standards to compare measurements at different sites; and comparative investigations of the analysis software. NDSC is a research network, so each system has its own history, design, and analysis, and has participated differently in validation campaigns. There are still some technological differences that may explain different accuracies. However, the comparison campaigns performed over the last decade have always proved to be very helpful in improving the measurements. To date, more efforts have been devoted to characterising ozone measurements than to temperature observations. The synthesis of the published works shows that the network can potentially be considered as homogeneous within $\pm 2 \%$ between $20-35 \mathrm{~km}$ for ozone and $\pm 1 \mathrm{~K}$ between $35-60 \mathrm{~km}$ for temperature. Outside this altitude range, larger biases are reported and more efforts are required. In the lower stratosphere, Raman channels seem to improve comparisons but such capabilities were not systematically compared. At the top of the profiles, more investigations on analysis methodologies are still probably needed. SAGE II and GOMOS appear to be excellent tools for future ozone lidar validations but need to be better coordinated and take more advantage of assimilation tools. Also, temperature validations face major difficulties caused by atmospheric tides and therefore require intercomparisons with the mobile systems, at all sites.
\end{abstract}

\section{Introduction}

The idea to establish a network of high-quality remotesounding research stations to observe and understand anthropogenic changes in the stratosphere was first discussed at a workshop in 1986. The result was the development of the international Network for the Detection of Stratospheric Change (NDSC). The initial goals of the network ${ }^{1}$ were to make the earliest possible identification of changes in the stratospheric ozone layer and related parameters, to study the variability of the stratosphere, to provide an independent calibration and validation of satellite sensors, and to provide data to test and improve multi-dimensional atmospheric chemical and dynamical models. These goals were subsequently expanded to include establishing the links between changes in stratospheric ozone, UV radiation at the ground, tropospheric chemistry, and climate. To meet such objectives, the quality of the data is one of the key issues and a major challenge the NDSC had to face.

While traditional methods such as balloon soundings and Dobson observations that have so far provided the longest data series were included in the NDSC, new instruments were qualified on the basis of being remote sensors, capable of continuous long-term field operation with the best accuracies. 
Lidar methods, having the required precision and range resolution, were proposed to be used for ozone, temperature and aerosol profile measurements. Lidar systems are also good candidates for atmospheric monitoring because they have low manpower requirements and modest maintenance costs. To provide the optimum latitude coverage within the obvious constraints of quality, funds and resources, it was proposed that the network would consist of 5-7 primary stations fully equipped with all the NDSC-defined instruments: polar, midlatitude, and tropical stations in both hemispheres, plus an equatorial station. Depending on specific site characteristics such as geography, orography or meteorology, a composite station may be formed with individual or a limited group of instruments at different sites within a given latitudinal or regional zone. Some complementary sites and mobile instruments are also associated with this network to expand the geographic coverage.

Considering the aims of this network, homogeneity of the data quality is required on both the temporal scale, for individual instruments, and on the horizontal scale over all the instruments involved in the network measuring the same geophysical quantity. The main limitations for trend detection, in addition to the natural variability, are temporal discontinuities. ${ }^{2}$ An instrumental bias that remains unchanged is not in theory a limitation for trend quantification. However, instrumental changes cannot be avoided with ground-based instruments running on a quasi-daily basis spanning decades. So instrumental drifts are always possible and are in fact a severe limitation for the investigations of long-term change. It also appears that the altitude locations of bias and instrumental drifts are often correlated.

For satellite validation, horizontal homogeneity of the correlative measurements is required in order to be able to quantify possible latitudinal bias of the instrument in space. The NDSC instruments are all research prototypes and have some differences in their design and final capabilities. Systematic differences that are of particular relevance for data quality must be detected, critically analyzed, and ruled out. The Steering Committee of the NDSC has therefore proposed to use, when and wherever possible, a mobile system alternately visiting the different stations of the network. ${ }^{1}$ Since ozone and temperature trends are expected to be small compared to the natural variability (around $10 \%$ and $1 \mathrm{~K}$ per decade respectively), the investigation of potential bias is more crucial than for stratospheric aerosol lidar measurements, where variability is mainly dominated by huge events such as volcanic eruptions or ice clouds in polar regions. For this

Philippe Keckhut was born in 1964 in Paris (France). He graduated in Optics and obtained his Doctorate at Paris in 1991. He was a National Research Council visiting scientist at

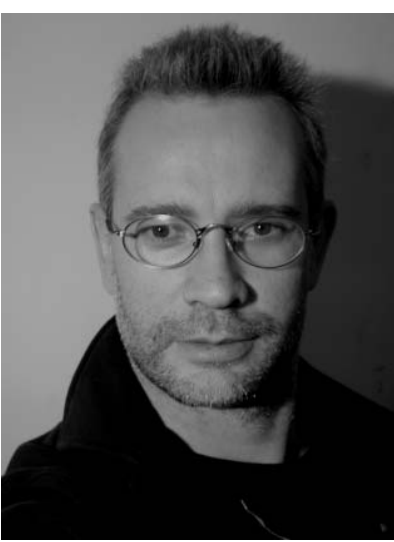

Philippe Keckhut NOAA-NCEP in 1994. He has pursued his research at Service d'Aéronomie (France) on inter-annual variability and trends in the middle atmosphere using lidar, rocket, radiosonde and satellite data series. He is co-responsible for two lidars involved in the NDSC network. He is also working on the upper troposphere climatology. He coordinates the 'Observation Services' of the Institut Pierre Simon Laplace. He has published 43 peer-reviewed papers in atmospheric sciences. reason, up to now, more effort has been expended on intercomparison campaigns for ozone and temperature profiles. Since the official inception of the network in 1991, several campaigns have been organized employing the NASA/ Goddard Space Flight Center (GSFC) mobile lidar. However, comparisons with the mobile lidar are not the only way to determine the quality of the data and other techniques have been investigated simultaneously in some campaigns, or more routinely at some sites. Comparisons with co-located radiosondes, or microwave radiometers are often performed, and also with close-by satellite measurements. There is no absolute reference instrument and the individual capabilities, and the network homogeneity, cannot be assured or quantified without undertaking all the NDSC validation exercises. Instruments launched into space are continually improving and their capabilities are close to what is obtainable from the ground in terms of sensitivity. Validation using ground-based instruments is therefore pushed to the limit. The use of assimilation allows, in theory, freedom from most of the possible discrepancies induced by geophysical causes and non-perfect spatio-temporal coincidences. However, some weighting of the data input to the model needs to be decided. The use of the reference data requires provision of standard values for bias and noise. After 10 years of operation, a first review of the validation exercises using NDSC ozone and temperature lidar is presented.

\section{Description of the instruments}

Atmospheric ozone profiles up to $45-50 \mathrm{~km}$ can be measured using the DIfferential Absorption Lidar (DIAL) technique, which requires two laser beams in the UV spectral region. ${ }^{3}$ The basic principle is to transmit two short laser pulses vertically into the atmosphere, one having a wavelength in an absorption band of ozone and the other not absorbed (or not so strongly absorbed) by ozone that can be used as reference. The ozone number density can then be retrieved from the difference in slope between the absorbed and non-absorbed lidar returns. Following major volcanic eruptions, it is necessary to avoid corruption of the backscattered signal caused by enhanced aerosols, and nitrogen Raman scattering can be used with the DIAL principle to derive ozone in the lower stratosphere under these conditions. ${ }^{4}$ On average, the ozone measurement precision achieved by NDSC lidars is around $1 \%$ up to $30 \mathrm{~km}$ $2-5 \%$ at $40 \mathrm{~km}$ and $5-25 \%$ at $50 \mathrm{~km}$.

Temperature profiles can be derived from Rayleigh scattering ${ }^{5}$ by assuming the atmosphere follows the ideal gas law and is in hydrostatic equilibrium. Temperatures are typically measured from 30 to around $80 \mathrm{~km}$ where atmosphere is not polluted by the presence of aerosols. Temperature profiles can be derived with better than $1 \mathrm{~K}$ precision from 30 to $70 \mathrm{~km}$. Above $70 \mathrm{~km}$, the temperature uncertainty increases rapidly with altitude due to photon counting uncertainties.

Basically, two type of lidar can be found.

(1) DIAL systems designed primarily for ozone density profiles operating at UV wavelengths and which can also measure temperature using the non-absorbed channel(s).

(2) Backscatter lidars that use a single wavelength are specifically used for temperature retrieval and can be based on visible or UV wavelengths. While the efficiency compared to DIAL is not entirely obvious, some groups using a temperature specific lidar system have chosen to use the second harmonic of the Nd:YAG laser, probably because the visible wavelength is somewhat easier to manage compared to UV, although tripled $\mathrm{Nd}$ :YAG and XeF lasers are also used.

In the presence of aerosols, Raman techniques can be used to extend the temperature profile downward. ${ }^{6}$ However, the lidar signal is directly affected by the aerosol attenuation and so can only be used for low to moderate aerosol loading. Alternative 
techniques, using the temperature dependence of the rotational-vibrational Raman spectrum, have also been investigated. However, the need for calibration limits the application of such a method for long-term monitoring. No specific actions have been planned within the NDSC on this issue and the lidar community continues to perform further investigations.

The main differences between the lidars involved in the NDSC are the size of their receiver telescope and their laser power, i.e., power-aperture product. However, these differences do not significantly affect the derivation methodology and their main effect is on the level of the counting noise that only restricts the altitude range of the measurement or the integration time for a given accuracy. Many variations in the actual lidar implementations can be noted, which can explain the differences observed between the various lidars involved in the NDSC. One difference is in the methods used to increase the dynamic range of the measurements. Usually, several channels with different sensitivity are set up and used simultaneously. To achieve this goal several technical solutions can be found and different signal processing methods have been reported to combine signals to provide a single profile through the entire stratosphere. The signal background levels also tend to be specific to a particular instrument design as is the way this is treated in the data analysis. The background noise level and the signal-induced-noise (SIN), which is due to the large initial burst of laser energy and the noise memory of the photomultiplier, can be mitigated with specific designs and analyses. The initialization of the temperature profile is strongly dependent on the lidar power and the methodology. The presence of aerosols, the filtering, or the alignment between the laser and the receiver field-of-view, are also some issues that have been resolved or at least investigated differently by each group.

It is difficult a priori to design an ideal lidar system for a long-term observations, accuracy, and reliability. In theory, most of the NDSC systems provide adequate designs and analyses to take care of all the well-known limitations mentioned previously. Ultimately, cross-validations or intercomparisons appear to be the only way to determine the quality of the different lidar systems. All the ozone and temperature lidars participating in the NDSC are listed in Table 1.
However, in this section only lidars that have participated in NDSC sanctioned validation exercises are reported. Technical details can be found in specific publications referenced later. The locations of the NDSC sites extend all over the latitudes from $80^{\circ} \mathrm{N}$ to $78^{\circ} \mathrm{S}$. Teams directly involved, reveal the large international community that concerns many countries all around the world (Canada, France, Germany, Italy, Japan, Norway, South Korea, The Netherlands, USA).

The GSFC stratospheric ozone lidar was developed by McGee et $a l^{7}$ as a mobile system to serve as a geographical transfer reference from one site to another. This instrument began development with funding from the NASA Upper Atmosphere Program in 1985 and has been a participant in the NDSC since its inception. This lidar is housed in a $45^{\prime}$ trailer allowing for transport around the world. The absorbed wavelength is provided by a $\mathrm{XeCl}$ excimer laser at $308 \mathrm{~nm}$ and the nonabsorbed wavelength at $351 \mathrm{~nm}$ from a XeF excimer laser (more recently changed to $355 \mathrm{~nm}$ from Nd:YAG third harmonic). Spectral separation is accomplished using beamsplitters and interference filters. Each of the elastically scattered signals is further split to improve the dynamic range; roughly $2-5 \%$ is used to retrieve data in the lower stratosphere. ${ }^{8}$ The two nitrogen Raman channels were added in late 1991 and tested at the first inter-comparison campaign at the Observatory of HauteProvence (OHP) in summer 1992 just after the eruption of Mount Pinatubo. This permits DIAL ozone retrieval in the presence of enhanced particle concentrations. ${ }^{9}$ The temperature profile is computed from the Rayleigh backscattering from the non-absorbed wavelength down to $28 \mathrm{~km}$ and using the Raman return down to $\sim 15 \mathrm{~km}$ when the atmosphere is relatively clean of aerosols and described by Gross et al. ${ }^{10}$ This instrument was used as the mobile reference and visits to many NDSC sites for collocated comparisons (Table 2).

One of the longest ozone and temperature series using lidar is available for $\mathrm{OHP}\left(43.9^{\circ} \mathrm{N}, 5.7^{\circ} \mathrm{E}\right)$. These two measurements are performed with two distinct instruments located at $\mathrm{OHP}$ that is part of the first NDSC site in the mid-northern hemisphere: The Alpine station. The ozone DIAL system operated by the Centre National de la Recherche Scientifique (CNRS) used a $\mathrm{XeCl}$ excimer laser at $308 \mathrm{~nm}$ and the third harmonic of a Nd:YAG laser at $355 \mathrm{~nm}$, respectively, for the

Table 1 List of ozone and temperature lidars in operation in the framework of NDSC ${ }^{a}$

\begin{tabular}{|c|c|c|c|c|c|}
\hline Site & Location & Measured parameters/PI & Team and laboratory & $\begin{array}{l}\text { NDSC } \\
\text { operation } \\
\text { since }\end{array}$ & Station \\
\hline Mobile lidar & - & O3, T/T. J. McGee & GSFC/NASA & 1991 & Mobile \\
\hline Eureka & $80.05^{\circ} \mathrm{N}, 86.42^{\circ} \mathrm{W}$ & $\mathrm{O} 3 / \mathrm{S} . \mathrm{Pal}$ & York University & 1993 & Arctic \\
\hline Ny-Ålesund & $78.92^{\circ} \mathrm{N}, 11.93^{\circ} \mathrm{E}$ & O3, T/R. Neuber, O. Schrems & AWI & 1991 & Arctic \\
\hline Thule & $76.53^{\circ} \mathrm{N}, 68.74^{\circ} \mathrm{W}$ & T/ G. Fiocco & Rome University & 1991 & Arctic \\
\hline Sondrestrom & $67.0^{\circ} \mathrm{N}, 50.9^{\circ} \mathrm{W}$ & T/ J. Thayer & SRI & 2002 & Complementary \\
\hline ALOMAR DIAL & $69.3^{\circ} \mathrm{N}, 16.0^{\circ} \mathrm{E}$ & O3/G. Hansen & NILU & 1995 & Complementary \\
\hline ALOMAR Backsc. & & T/Hauchecorne & CNRS/SA & 1993 & Complementary \\
\hline Hohenpeissenberg & $47.80^{\circ} \mathrm{N}, 11.02^{\circ} \mathrm{E}$ & O3, T/H. Claude & $\mathrm{MOH}$ & 1987 & Complementary \\
\hline OHP/DIAL & $43.94^{\circ} \mathrm{N}, 5.71^{\circ} \mathrm{E}$ & O3/S. Godin & CNRS/SA & 1991 & Alpine \\
\hline OHP Backscatter & & T/A. Hauchecorne & CNRS/SA & 1991 & Alpine \\
\hline Toronto & $43.8^{\circ} \mathrm{N}, 79.5^{\circ} \mathrm{W}$ & O3, T/S. Pal & York University & 1990 & Complementary \\
\hline Suwon DIAL & $37.2^{\circ} \mathrm{N}, 127.6^{\circ} \mathrm{E}$ & O3/C. H. Lee & Kyung Hee University & 1992 & Complementary \\
\hline Suwon Backscatter & & T/C. H. Lee & Kyung Hee University & 1995 & Complementary \\
\hline Tsukuba & $36.05^{\circ} \mathrm{N}, 140.13^{\circ} \mathrm{E}$ & O3/H. Nakane & NIES & 1991 & Complementary \\
\hline TMF & $34.4^{\circ} \mathrm{N}, 117.7^{\circ} \mathrm{W}$ & O3, T/I. S. McDermid & JPL & 1991 & Complementary \\
\hline MLO DIAL & $19.54^{\circ} \mathrm{N}, 155.58^{\circ} \mathrm{W}$ & O3, T/I. S. McDermid & JPL & 1993 & Hawaii \\
\hline MLO Backscatter & & T/ J. Barnes & NOAA-CMDL & 1994 & Hawaii \\
\hline \multirow[t]{2}{*}{ La Reunion } & $21.8^{\circ} \mathrm{N}, 55.5^{\circ} \mathrm{E}$ & T/H. Bencherif & La Reunion University & 1994 & Complementary \\
\hline & & O3/ J. L. Baray & La Reunion University & 2000 & Complementary \\
\hline \multirow[t]{2}{*}{ Lauder } & $45.05^{\circ} \mathrm{S}, 169.68^{\circ} \mathrm{E}$ & O3, T/D. Swart & RIVM & 1994 & New Zealand \\
\hline & & T/ Stefanutti & CNR/IROE & 1994 & New Zealand \\
\hline DDU & $66.67^{\circ} \mathrm{S}, 140.01^{\circ} \mathrm{E}$ & O3/S. Godin & CNRS/SA & 1991 & Antarctic \\
\hline McMurdo & $77.85^{\circ} \mathrm{S}, 166.70^{\circ} \mathrm{E}$ & T/A. Adriani & CNR/IFA & 1991 & Not NDSC \\
\hline
\end{tabular}

${ }^{a}$ Instruments in bold have been compared with the mobile system. O3 and $\mathrm{T}$ refer respectively to ozone and temperature while PI mean principal investigator or the person responsible for the scientific data quality. See the acronym list for "Team and laboratory". 
Table 2 Intercomparison campaigns with the mobile GSFC lidar involved

\begin{tabular}{lll}
\hline Campaign name & Location & Date \\
\hline Informal & TMF California & Oct-Nov 1988 \\
STOIC & TMF California & Jul-Aug 1989 \\
OHP 92 & OHP France & Jul-Aug 1992 \\
OPAL & Lauder New Zealand & Apr 1995 \\
MLO3 & MLO Hawaii & Aug 1995-Feb 1996 \\
STRAT & TMF California & Feb-Mar 1997 \\
OTOIC & OHP France & Jun-Jul 1997 \\
NAOMI & Ny-Ålesund Svalbard & Jan-Feb 1998 \\
\hline
\end{tabular}

absorbed and the non-absorbed wavelengths. A multi-channel monochromator separates the received wavelengths including (as the GSFC system) Raman channels and low sensitivity elastic channels. This instrument, redesigned in December 1993, follows a previous prototype that was in operation since 1986. This first instrument described by Godin et al.,${ }^{11}$ had only two channels, and two measurement sequences had to be made sequentially with, respectively, the full and a reduced laser power in order to cover the full $18-45 \mathrm{~km}$ altitude range. The temperature is obtained with an independent instrument, operating since 1984, using the second harmonic of a Nd:YAG laser at $532 \mathrm{~nm}$ using a method described by Hauchecorne and Chanin. ${ }^{5}$ Since its inception, this instrument has undergone several modifications. ${ }^{12}$ Prior to 1991 , the low sensitivity channel was constructed similarly to the GSFC lidar system; now a second independent smaller telescope is used to collect the light from the lower altitudes. This configuration, described by Keckhut et al., ${ }^{12}$ has been preferred to check alignments between the emitted beam and the receiver field-of-view. This lidar was redesigned in September 1994 to increase the receiving area and the vertical resolution, and to change the computer and the analysis software. The signals from low and high channels are first merged together before computing the temperature profile. This method differs from most of the DIAL users who derive temperature first and then merge the geophysical quantities.

A complementary ozone DIAL lidar is located at Hohenpeissenberg $\left(47.8^{\circ} \mathrm{N}, 11.0^{\circ} \mathrm{E}\right)$ and is closely associated with the Alpine Station. This lidar system, in operation since the end of 1987, uses a setup very similar to that described by Werner et al., ${ }^{13}$ and Steinbrecht et al. ${ }^{14}$ One of the main differences to the previous systems mentioned here is the use of a single $\mathrm{XeCl}$ excimer laser to generate the absorbed wavelength at $308 \mathrm{~nm}$ and a hydrogen Raman shifter for the reference wavelength at $353 \mathrm{~nm}$. To extend the altitude range, the lidar is operated successively in two modes. The first one dedicated to low altitude inserts a neutral density filter, with a transmission of $5 \%$, in front of the receiver. No filter is applied in the second mode but raises the cut off altitude of the chopper to limit the maximum count rate. Before the derivation of ozone and temperature, both signals are merged with appropriate weights to provide a continuous return signal similar to the OHP temperature lidar analysis. The interactive determination of the ratio between both the channels also provides a check for counter linearity. The DIAL ozone data series has been measured consistently without any changes in the instrument parameters.

A similar wavelength generation, with a hydrogen Raman cell, was used for the DIAL ozone system in operation at Suwon in South Korea $\left(37.2^{\circ} \mathrm{N}, 127.6^{\circ} \mathrm{E}\right)$. In addition to the stratospheric system, a deuterium Raman cell, providing the 291 and $319 \mathrm{~nm}$ wavelengths, was also implemented for extending ozone measurements throughout the whole troposphere by Park et al. ${ }^{15}$

The Jet Propulsion Laboratory (JPL) Table Mountain Facility (TMF) in California $\left(34.4^{\circ} \mathrm{N}, 117.7^{\circ} \mathrm{W}\right)$ acts as an intercomparison and test research site for many of the NDSC primary instruments. For reasons of not duplicating a northern mid-latitude primary site it was decided that this would also be a complementary station. A DIAL system measuring both ozone and temperature has been in routine operation since 1988 by McDermid et al. ${ }^{16}$ This is a very large power-aperture lidar system $(100 \mathrm{~W} / 1 \mathrm{~m})$ at a high altitude location $(2300 \mathrm{~m})$ and measures ozone profiles to $>50 \mathrm{~km}$ and temperature to $>90 \mathrm{~km}$. It also uses an a $\mathrm{XeCl}$ excimer laser at $308 \mathrm{~nm}$ and originally generated the reference wavelength at $353 \mathrm{~nm}$ by stimulated Raman shifting in a hydrogen cell although this was replaced by a tripled Nd:YAG laser at $355 \mathrm{~nm}$ in 2000. It was also supplemented with a tropospheric ozone DIAL operating at 289/299 nm by Raman shifting of a quadrupled Nd:YAG laser in deuterium and hydrogen. This now allows ozone profiles to be measured from $4 \mathrm{~km}$ to $>50 \mathrm{~km}$ altitude. The stratospheric ozone DIAL instrument has participated in many ozone inter-comparisons and was the first prototype used by JPL to design the system implemented at Hawaii. The GSFC mobile lidar has, and continues, to undergo extensive testing and intercomparison at TMF. In 1999 the entire TMF dataset was reanalyzed by Leblanc et al. ${ }^{17}$ using a new, improved version of the analysis software.

An ozone DIAL system was also accepted as a complementary instrument at the National Institute for Environmental Studies (NIES) in Tsukuba, Japan $\left(36.1^{\circ} \mathrm{N}, 140.1^{\circ} \mathrm{W}\right)$ for ozone and temperature measurements. The system is similar to the GSFC lidar and operates 6 channels simultaneously.

The JPL team also operates a DIAL system at Mauna Loa Observatory $\left(19.5^{\circ} \mathrm{N}, 155.6^{\circ} \mathrm{W}\right)$ in Hawaii, since 1993 . This instrument is part of the northern tropical primary NDSC site. Temperature, ozone, and aerosol profiles are derived with this lidar using similar hardware and software to those used at TMF. Two Raman channels have been implemented on this system to avoid contamination by stratospheric aerosols. Simultaneously with the relocation from a trailer to the NDSC building, a new Nd:YAG laser was implemented in April 2001. Also at MLO (Mauna Loa Observatory), the longest aerosol lidar series has been obtained with the National Oceanic and Atmospheric Administration (NOAA) backscatter lidar. Recently these data have also been used to derive temperature profiles.

At Lauder, New Zealand $\left(45.0^{\circ} \mathrm{S}, 169.7^{\circ} \mathrm{E}\right)$, the southern hemisphere mid-latitude primary station of the NDSC, a DIAL lidar was implemented and measurements started in 1994 by the National Institute of Public Health and the Environment (RIVM) of The Netherlands. Several changes in both its design and software have been made by Brinksma et al. ${ }^{18}$ since its inception. Altitude range and resolution were adjusted to better take into account signal-induced-noise. Effects related to the field-of-view and altitude offset, were also investigated. In the analysis, improvements were made relating to the temperature dependence of the Rayleigh extinction correction, and filtering.

In the southern hemisphere, CNRS and the University of La Réunion (Laboratoire de Physique de l'Atmosphere) implemented a Rayleigh lidar for temperature measurements at $\mathrm{La}$ Réunion Island $\left(21.8^{\circ} \mathrm{S}, 55.5^{\circ} \mathrm{W}\right)$ in 1993 . This instrument is very similar to the OHP system and uses the same algorithm. This instrument has also been enhanced with complementary channels for tropospheric ozone, cirrus, temperature, and water vapor measurements as described by Baray et al. ${ }^{19}$ A new DIAL ozone lidar in a trailer built in collaboration between CNRS and the university of Geneva was also installed in 2000. The design of this lidar is also very close to the new OHP instrument.

There are several instruments operating in polar regions and in the northern hemisphere, the primary site is called the Arctic Station. Several sites located in the Arctic region compose this station. An ozone DIAL system was in operation at Eureka, Canada $\left(80.1^{\circ} \mathrm{N}, 86.4^{\circ} \mathrm{W}\right)$ from 1993 to 2000 . The design and data analyses are similar to the system at Toronto, which was operated by the same group. However, due to the high latitude 
location, ozone and temperature measurements were only possible during the polar night period from November to March. A DIAL system providing ozone density and temperature profiles was installed in 1990 in Toronto, Canada $\left(43.7^{\circ} \mathrm{N}, 79.4^{\circ} \mathrm{W}\right)$ ) by CRESTech and York University. Raman channels were added in 1995. This system is similar to the Eureka system mentioned above. Signals from three altitude ranges are first merged to produce a single raw data profile, as done for the temperature lidar at OHP and as opposed to the other teams who first derive the ozone density and then merge the 3 density profiles. ${ }^{20}$ The ozone profile is computed from the single composite signal. Temperature profiles are also derived from the $353 \mathrm{~nm}$ signals with a very similar procedure to the other groups.

A lidar installed in Thule, Greenland $\left(76.5^{\circ} \mathrm{N}, 68.7^{\circ} \mathrm{W}\right)$ by the University of Rome, described by Marenco et al., ${ }^{21}$ provides temperature using the second harmonic of a Nd:YAG laser, similar to OHP. Measurements have been carried out at this location since 1993, mostly during nighttimes but occasionally in daylight, and on a schedule depending on weather conditions. This lidar was originally set up for lower stratospheric aerosol measurements. The transmitter is based on a two-stage Nd:YAG laser with a second harmonic generator emitting at $532 \mathrm{~nm}$, a repetition rate of $40 \mathrm{~Hz}$, and an energy of $300 \mathrm{~mJ}$ per pulse. The receiver includes a $0.8 \mathrm{~m}$ diameter telescope. A rotating disk (chopper) protects the photomultiplier from over loading due to intense signal from the lowest levels.

Since the winter of 1993, a Rayleigh/Mie lidar has been in operation at the ARCtic LIdar TEchnology (ARCLITE) facility located at the National Science Foundation's (NSF) Sondrestrom upper atmospheric research site near the town of Kangerlussuaq, Greenland (67.0N, 309.1E). This lidar system is capable of night and day operations and was described by Thayer et $_{\text {al. }}{ }^{22}$ Recently (2002), the Sondrestrom ARCLITE facility was designated as a primary instrument in the NDSC Arctic Station. While the GSFC mobile system has not yet visited this site, the temperature data derived there have been intensively compared with several other sources as National Centers for Environmental Prediction (NCEP) fields, ${ }^{23}$ satellite temperature profiles from NASA's Cryogenic Limb Array Etalon Spectrometer (CLAES) and Microwave Limb Sounder (MLS) instruments onboard the Upper Atmosphere Research Satellite (UARS), Polar Ozone and Aerosol Measurement satellite (POAM III), Japan's Improved Limb Atmospheric Spectrometer (ILAS) instruments and NASA's Sounding of the Atmosphere using Broadband Emission Radiometry (SABER) instrument onboard the Thermosphere, Ionosphere, Mesosphere, Energetics and Dynamics spacecraft (TIMED).

Another polar lidar has been in operation at Ny-Ålesund, Spitsbergen $\left(78.9^{\circ} \mathrm{N}, 11.9^{\circ} \mathrm{E}\right)$ since 1988 . It is a DIAL system providing ozone density and temperature profiles. During winter 1993-1994 this system was equipped with Raman channels, and daylight channels were added in spring 1997 to enable year-round operations. The Artic Lidar Observatory for Middle Atmosphere Research (ALOMAR) described by Thrane and van Zahn, ${ }^{24}$ was established in 1993, and is located on the North-Norwegian island of Andoya $\left(69.3^{\circ} \mathrm{N}\right.$, $\left.16.0^{\circ} \mathrm{E}\right)$. The DIAL ozone lidar follows the standard design, with a $\mathrm{XeCl}$ excimer laser as an emitter (308 $\mathrm{nm}$ ), a hydrogenfiled Raman cell converting about $15 \%$ of the laser emission to $353 \mathrm{~nm}$, and a $1 \mathrm{~m}$ Newtonian telescope as a receiver (Hoppe et al. $^{25}$ ). A Rayleigh-Mie-Raman lidar system emitting at the 3 wavelengths corresponding to the harmonics of the $\mathrm{Nd}$ :YAG laser is also in operation at the same site.

There are several lidars operating in the Antarctic. At Dumont D'Urville (DDU, $66.7^{\circ} \mathrm{S}, 140.0^{\circ} \mathrm{E}$ ) the DIAL ozone lidar should, in theory, be able to measure temperature profiles. However, the signal return was too low for temperature profiles to reach an altitude higher than $50-60 \mathrm{~km}$ and the measurement frequency too small to catch the main dynamic features. So it was decided not to archive them. A lidar dedicated to aerosol and temperature measurements was installed at McMurdo Station on Ross Island $\left(78^{\circ} \mathrm{S}, 167^{\circ} \mathrm{E}\right)$ during the 1990 spring by Gobbi et al. ${ }^{26}$ in support of a balloon-borne campaign. Since the 1991 campaign, this system has operated every winter to study the temperature variability and polar stratospheric cloud occurrence (Adriani et al. ${ }^{27}$ ). The basic design of this lidar system is similar to the other Italian instrument operating at Thule.

\section{Comparison campaigns with the GSFC mobile lidar}

The mobile lidar developed by GSFC has participated in a number of inter-comparison campaigns at NDSC sites where lidars are operated (Table 2). While the Table Mountain site in California was chosen for the first comparisons, other primary sites easy to access (such as Observatory of Haute-Provence, Lauder and Hawaii) and where lidars are already running in a routine mode for a long time, followed closely. Then the other sites located at higher latitudes have been proposed. While the mobile lidar cannot be considered as an absolute reference, the comparisons have been found to be very helpful to better understand the reliability of the lidars, and to reveal and aid in mitigating various problems.

\subsection{Ozone comparisons}

A first lidar inter-comparison campaign between the fixed JPL stratospheric lidar and the GSFC lidar was organized in October-November 1988 , by McDermid et al. ${ }^{28,29}$ The two lidars used the same wavelength and so, to reduce the possible interferences, both instruments were operated alternatively for several hours each. While a global agreement of $\pm 5 \%$ was obtained from 30 to $40 \mathrm{~km}$, outside this altitude range, the campaign revealed some instrumental problems associated with algorithm errors and signal-induced-noise effects. A second campaign called STOIC (STratospheric Ozone Intercomparison Campaign), which also represented the first formal NDSC intercomparison ${ }^{30-32}$ following the established protocol, was organized during the following summer (July-August 1989). A $\pm 5 \%$ agreement region was obtained from 26 to $35 \mathrm{~km}$ and some bias of up to $10-15 \%$ between the both lidars, remains outside this height range. Other instruments measuring ozone were used during this campaign including microwave radiometers, ROCOZ rocket sondes, balloon ozonesondes, and Stratospheric Aerosol and Gas Experiment (SAGE) satellite measurements. The comparison between the mobile lidar, the JPL lidar, and the few coincident ozonesondes showed an agreement of $\pm 2 \%$ from 18 to $36 \mathrm{~km}$. Above this altitude, the JPL lidar revealed a similar agreement with SAGE up to $42 \mathrm{~km}$.

The next inter-comparison was organized at OHP in JulyAugust 1992. The conditions of these inter-comparisons between the fixed CNRS lidar and the GSFC mobile were difficult because this campaign just came after the eruption of Mount Pinatubo and most of the stratosphere was strongly affected by volcanic aerosol particles. ${ }^{9}$ A second comparison campaign at OHP took place from 1-18 July 1997. Braathen et al. ${ }^{33}$ have reported that two ozone lidars agreed very well in the $30-40 \mathrm{~km}$ range $(2 \%)$. In the 20 to $30 \mathrm{~km}$ range there was a discrepancy of $5 \%$. Below $20 \mathrm{~km}$ the difference varies between $\pm 7 \%$, but this can be explained by the larger variability at this height range together with the fact that the two instruments could not measure at exactly the same time. Above $40 \mathrm{~km}$ the differences increased rapidly. Comparison with ozonesondes gave a better agreement with the CNRS lidar in the 20-30 km range.

Analysis of the blind OPAL (Ozone Profiler Assessment at Lauder) comparison showed that the GSFC mobile lidar was in quite good agreement with SAGE II from 20 to $40 \mathrm{~km} .{ }^{34}$ 
Conversely, large differences were observed with sondes and the RIVM lidar $(10 \%)$. Using information gleaned from the blind intercomparison, the investigators were able to refine and improve their analysis algorithms. For example, the pulse-pile up effect (saturation) was reduced and signal-induced-noise corrections were implemented in the RIVM analysis tool. Microwave radiometer and ozonesonde results were also improved. The GSFC team discovered an altitude shift of $187 \mathrm{~m}$ and corrected it. These changes resulted in a new 'refined' dataset for the intercomparison. The subsequent reanalysis using the refined data revealed a better agreement between the lidars of $5 \%$ from 20 to $45 \mathrm{~km} .{ }^{35}$ Comparisons with ozonesondes were also improved and a mean difference of $5 \%$ was observed by Boyd et al., ${ }^{36}$ but with a lot of structures that differed up to $10 \%$. Both lidars differed by $10 \%$ with the microwave measurements. Above $45 \mathrm{~km}$, the measurements do not agree well but filtering and background effects in the lidar analysis are suspected.

Subsequent to the OPAL Campaign, lidar results were improved with better Rayleigh attenuation corrections and by including the temperature dependence of the ozone absorption cross-section in the analysis. Ozonesonde measurements were also improved with respect to altitude shifts, and the solutions in the electrochemical concentration cells (ECC) were modified. A constant correction with altitude was applied to SAGE results with the approval of SAGE team. The microwave retrieval algorithm was improved further. A new intercomparison was done using 3 years of data obtained with the different permanent instruments at Lauder, plus SAGE. The RIVM lidar did not show any significant bias, between 20 and $35 \mathrm{~km}$, larger than $1.5 \pm 2 \%$ compared to the ozonesondes ( 75 pairs) and $2.5 \pm 2.5 \%$ compared to SAGE ( 28 pairs). Below $20 \mathrm{~km}$, the 4.96 version of SAGE data are definitively biased as are the lidar above $45 \mathrm{~km}$. Below $20 \mathrm{~km}$ lidar and sondes still present significant differences of $9 \%$ with a noise from $2-4 \%$. Microwave results compare better with lidar (140 pairs) but still show significant differences $(4 \pm 2 \%)$ above
$45 \mathrm{~km}$ and confirm significantly that lidar is biased in this region by $5 \pm 5 \%$.

The MLO3 campaign was carried out at the Mauna Loa Observatory in August-September 1996 and studied by McDermid et al., ${ }^{37}$ and McPeters et $a l^{38}$ Almost all the instruments (Fig. 1) agreed to within $\pm 10 \%$, and most agreed within $\pm 5 \%$. The two lidars, the microwave instrument, and SAGE II agreed within $\pm 5 \%$ between 22 and $43 \mathrm{~km}$, providing strong evidence that the lidars and the microwave instrument are making good accurate measurements in this range. The JPL lidar, microwave instrument and SAGE II continue to agree within $5 \%$ up to $50 \mathrm{~km}$. The Goddard lidar, ozonesonde, and SAGE II agree within $5 \%$ down to $18 \mathrm{~km}$. The SAGE II disagreement with the balloon profile below $18 \mathrm{~km}$ is due to some known algorithm problems.

The GSFC lidar was compared with the permanent lidar of the Alfred Wegner Institute (AWI) located at Ny-Ålesund, Spitzbergen, during a campaign called NAOMI (Ny-Ålesund Ozone Measurements Intercomparison, January-February 1998 ). In the 20 to $30 \mathrm{~km}$ altitude range, $\pm 2 \%$ agreement is observed while a larger bias of $5-10 \%$ is observed by Steinbrecht et al. ${ }^{39}$ above and below. Below $20 \mathrm{~km}$, the comparison of the AWI lidar and the co-located ECC sondes show $\pm 2 \%$ agreement, suggesting a possible bias in the GSFC profiles. However, between 30 and $40 \mathrm{~km}$, the simultaneous microwave measurement seems to suggest that AWI lidar is affected by bias, probably associated with noise processing.

\subsection{Temperature comparisons}

During the first OHP inter-comparison (summer 1992), temperature profiles deduced from the GSFC lidar and from the fixed OHP lidar dedicated for temperature were compared by Singh et al. ${ }^{40}$ Mean differences (Fig. 2), less than 1\%, were obtained from 35 to $75 \mathrm{~km}$. Below $35 \mathrm{~km}$ larger bias (2\%) was observed due to the presence of aerosols; Raman channels were only implemented on the GSFC system. Despite the agreement
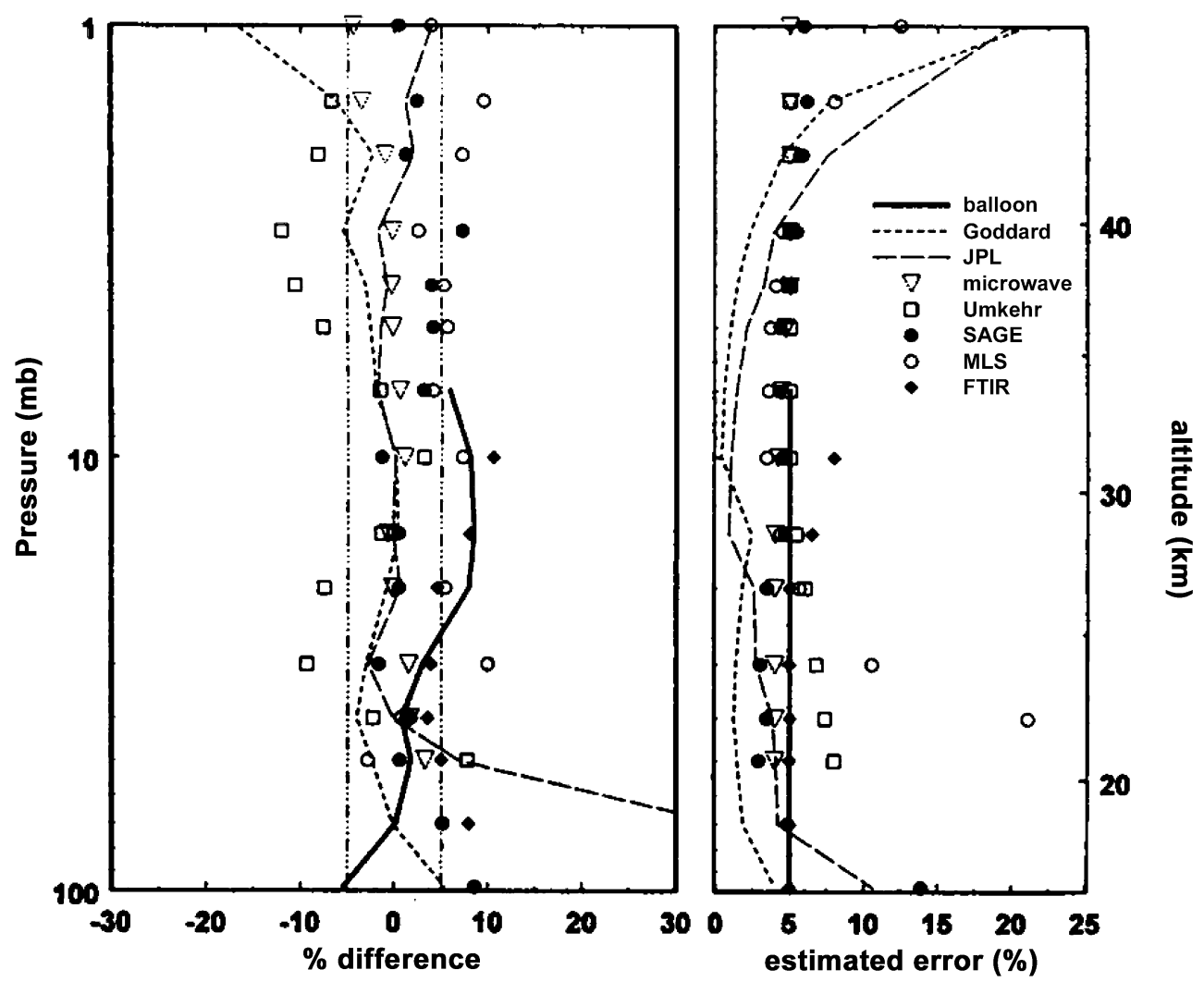

Fig. 1 Percent deviation of the comparison average for several instruments measuring ozone profiles from a "consensus" reference (left). The estimated percent error for each measurement (right) from McPeters et al. ${ }^{38}$ (Copyright 1999, Journal of Geophysical Research). 


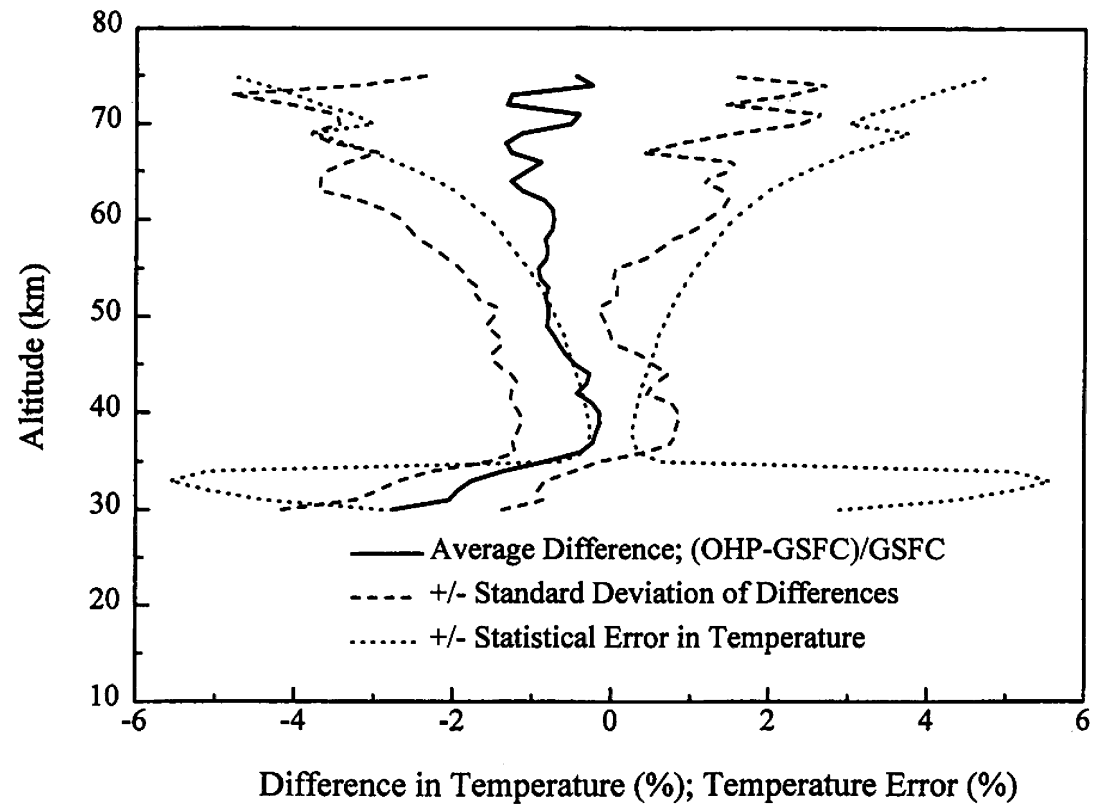

Fig. 2 Mean statistical difference of 18 coincident temperature profiles obtained by two independent lidars operating at OHP (from Singh et al. ${ }^{40}$, Copyright 1996, Journal of Geophysical Research).

is not so good for trend estimates compared to the theoretical accuracy ( $<$ a few tenths of a Kelvin), this first inter-comparison was very promising. The second inter-comparison ${ }^{32}$ was carried out in summer 1997 after the Rayleigh lidar system underwent a major change to the counting system in September 1994. The difference between the two lidars was within $1.5 \%$, depending on the altitude. Since the maximum differences were associated with the maximum temperature gradients, this could suggest that an altitude difference exists between the two systems. However, 7 cases showed a constant $1.5 \%$ change according to altitude. This may suggest an additional problem in initialization or background estimation on one of the systems superimposed on the possible altitude bias. A comparison ${ }^{41}$ of the OHP lidar with a very similar Rayleigh lidar located $500 \mathrm{~km}$ away and operating simultaneously reveals a mean difference smaller than $1 \mathrm{~K}$ with variability equal to $2 \mathrm{~K}$ from 3 to $65 \mathrm{~km}$.

Temperature comparisons made at TMF in the spring 1992 campaign showed differences less than $1 \mathrm{~K}$ at $40 \mathrm{~km}$, increasing up to $3 \mathrm{~K}$ at $50 \mathrm{~km}$. The lidars were not operated simultaneously and investigations using NCEP analyses revealed an important role of atmospheric tides ${ }^{42}$ that should be taken into account. A larger difference, as large as $5 \mathrm{~K}$, that could not be attributed to tides was noted at $30 \mathrm{~km}$. However at that time there were a lot of aerosols due to the Mount Pinatubo eruption.

\section{Inter-comparison with satellites}

\subsection{Ozone comparisons}

SAGE II provided a very important tool for evaluating ozone lidars and it was used extensively because of its availability over a long time period. The TMF lidar, which was compared in several successive studies, ${ }^{43,44}$ showed agreement within $6 \%$ between 30 and $40 \mathrm{~km}$ with an increasing bias with altitude up to $13 \%$ above $40 \mathrm{~km}$. A typical lidar-SAGE difference vertical profile can be found in Fig. 3. The good accuracy of the SAGE II profile in the mid stratosphere range permits the use of these global data to evaluate other ozone lidars that have not been compared with the GSFC mobile instrument. Such was the case for the NIES system operating at Tsukuba by Nakane et al. ${ }^{45}$ Comparisons with SAGE II were conducted and revealed average mean differences smaller than $10 \%$ between 15 and $50 \mathrm{~km}$. None of them were significant. Between 22 and $36 \mathrm{~km}$ the mean difference is smaller than $2 \%$. An increasing bias with altitude can be observed above $37 \mathrm{~km}$ of $10 \%$. Most of the DIAL lidars, deployed within the NDSC, have been compared with SAGE II. Three zones can be identified. The best agreement, of $5-10 \%$, can be found between 25 and $40 \mathrm{~km}$. Outside this range larger mean differences are reported at all sites, mainly due to the lidar methods. Also, in the lower stratosphere SAGE II exhibits a larger uncertainty. In addition, the spatio-temporal ozone variability is larger in the lower stratosphere due to horizontal transport and because the SAGE II-lidar coincidences are not perfect it may induce larger discrepancies.

UARS also provided a good opportunity for evaluating lidars since a number of them took part in the validation of the ozone profiles derived by several experiments onboard the satellite. Bruhl et al. ${ }^{46}$ have reported a bias of $5-10 \%$ in the 10 $20 \mathrm{hPa}$ region $(\approx 25-30 \mathrm{~km})$ and differences of $\pm 5 \%$ above in the comparison of Halogen Occultation Experiment (HALOE) ozone measurements with all the other correlative measurements. Most of the NDSC lidars (TMF, Hohenpeissenberg,

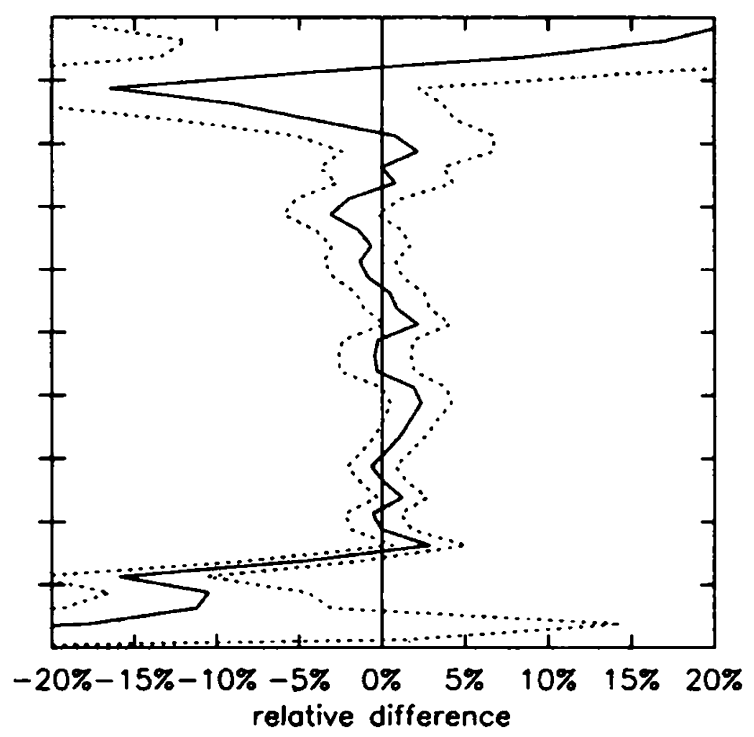

Fig. 3 Averages of the paired SAGE II Lauder ozone lidar between March 96 to January 98 (from Brinskma et al. ${ }^{18}$, Copyright 2000, Journal of Geophysical Research). 
GSFC) agreed within $10 \%$ between $20-2 \mathrm{hPa}(\approx 25-45 \mathrm{~km})$. DDU and OHP provided insufficient coincidences. Above $2 \mathrm{hPa}(\approx 45 \mathrm{~km})$, the differences increase, reaching $15-25 \%$ at $1 \mathrm{hPa}(\approx 50 \mathrm{~km})$. CLAES measurements were also compared with GSFC and TMF by Baily et al. ${ }^{47}$ Ozone profiles agreed within $10 \%$ except below $100 \mathrm{hPa}(\approx 15 \mathrm{~km})$ for GSFC system, where the mean differences increased up to $30 \%$, and around $1 \mathrm{hPa}(\approx 50 \mathrm{~km})$ with the TMF lidar where a bias of $25 \%$ appeared. The overall comparison made by Froidevaux et al. ${ }^{48}$ between the TMF lidar and CLAES data between 10 and $2 \mathrm{hPa}$ $(\approx 25-30 \mathrm{~km})$ were within $5 \%$. MLS was only compared with the TMF lidar and showed a similar agreement as CLAES.

Some comparisons were performed between the Global Ozone Monitoring Experiment (GOME) onboard the European Remote Sensing Satellite (ERS-2) by Burrows et al. ${ }^{49}$ and the lidar located at Lauder, New Zealand. Mean differences were within $\pm 10 \%$ from 10 to $45 \mathrm{~km}$ as reported by Meijer et al. ${ }^{50}$ Such experiments can be used for long-term comparisons because instruments, using a very similar method, are expected to be launched successively in the future. However, the satellite product includes a priori information, and spectral calibration can introduce significant bias. Also, strong biases related to the Solar Zenith Angle (SZA) have been reported.

\subsection{Temperature comparisons}

Several lidars located at mid-latitude sites have been compared by Wild et al. $^{42}$ using NCEP data as a geographical transfer reference. This study included the NDSC lidars at TMF and OHP. At first glance the dispersion between the lidars appears quite large, from 4 to $6 \mathrm{~K}$. However, adjustments related to the time of the day of the measurements reduce the dispersion to $4 \mathrm{~K}$ at $1 \mathrm{hPa}(\approx 50 \mathrm{~km}$, where stratospheric tides are the largest) with most of the measurements within less than $2 \mathrm{~K}$. Comparisons with MLS/UARS (Fig. 4) report also large differences around $1-2 \mathrm{hPa}(\approx 40-50 \mathrm{~km})$. The geophysical nature of such disagreement is obvious in Fig. 4, as the same lidar have been compared with MLS at different locations (and so different time of measurements with MLS) and gave different bias. Comparisons of OHP lidar and NCEP analyses have continued and confirm the impact of tides not only in data comparisons but also in NCEP continuity. As well as SAGE, NCEP analyses can provide a preliminary comparison for temperature lidars. However, due to the problem of tides, it cannot provide validation accuracy better than several Kelvin. Temperatures retrieved by NIES during winter 1995-1996 were compared with NCEP, with a rocket climatology over Ryori, Japan, and with the CIRA model by Namboothiri et al. ${ }^{51}$ The maximum deviation was up to $15 \mathrm{~K}$. Comparisons with rockets launched the same day showed differences less than $10 \mathrm{~K}$, no systematic differences, and most of the differences within $\pm 5 \mathrm{~K}$.

The lidar data obtained in 1994 at La Reunion were also compared with NCEP analyses. Mean differences of less than $2 \mathrm{~K}$ were obtained except near the stratopause where the mean differences increased to $4 \mathrm{~K}$. These differences were in good agreement with other lidar comparisons mentioned previously $^{41}$ and were probably related to tidal effects. At $10 \mathrm{hPa}(\approx 30 \mathrm{~km})$, colder temperatures $(4 \mathrm{~K})$ were observed by the lidar but were probably associated with the interfering presence of aerosols.

Again, UARS provided many opportunities to compare simultaneous temperature measurements from the ground and space. TMF, OHP and the GSFC lidar (at Lauder in 1992 and 1994) were compared with HALOE by Hervig et al. ${ }^{52}$ While the GSFC and the OHP comparisons show a similar bias in the profiles with an alternating pattern of 5-10 K, the GSFC at Lauder in 1994 showed a positive bias of $5 \mathrm{~K}$, in agreement with TMF comparisons. The time window used for data selection was quite large and some tidal interference is therefore expected. Comparisons of these three lidars with CLAES performed by Gille et al. ${ }^{53}$ were conclusive and in good agreement revealing a negative bias of $1-2 \mathrm{~K}$ around $5 \mathrm{hPa}$ $(\approx 38 \mathrm{~km})$ and a positive bias at $1 \mathrm{hPa}(\approx 50 \mathrm{~km})$ increasing up to $3-4 \mathrm{~K}$ at $0.1 \mathrm{hPa}(\approx 80 \mathrm{~km})$. The comparisons by Fishbein et al. ${ }^{54}$ with MLS show a dispersion of $4 \mathrm{~K}$. However, GSFC and TMF on one side, and GSFC and OHP on the other, agreed within $1 \mathrm{~K}$ during comparisons at the same sites and a difference of $4 \mathrm{~K}$ between the two sites was probably due again to atmospheric tides. The comparison of the OHP lidar and the Improved Stratospheric and Mesospheric Sounder (ISAMS) temperature experiment revealed bias profiles of $\pm 2 \mathrm{~K}$ with the same lidar data mentioned before. The selection of lidar measurements ${ }^{55}$ where the integration period matched better the ISAMS observation time reduces this bias to less than $0.5 \mathrm{~K}$ from 5 to $0.2 \mathrm{hPa}(\approx 38-70 \mathrm{~km})$ showing the importance of temporal coincidence in the intercomparisons and reflecting the influence of tides.

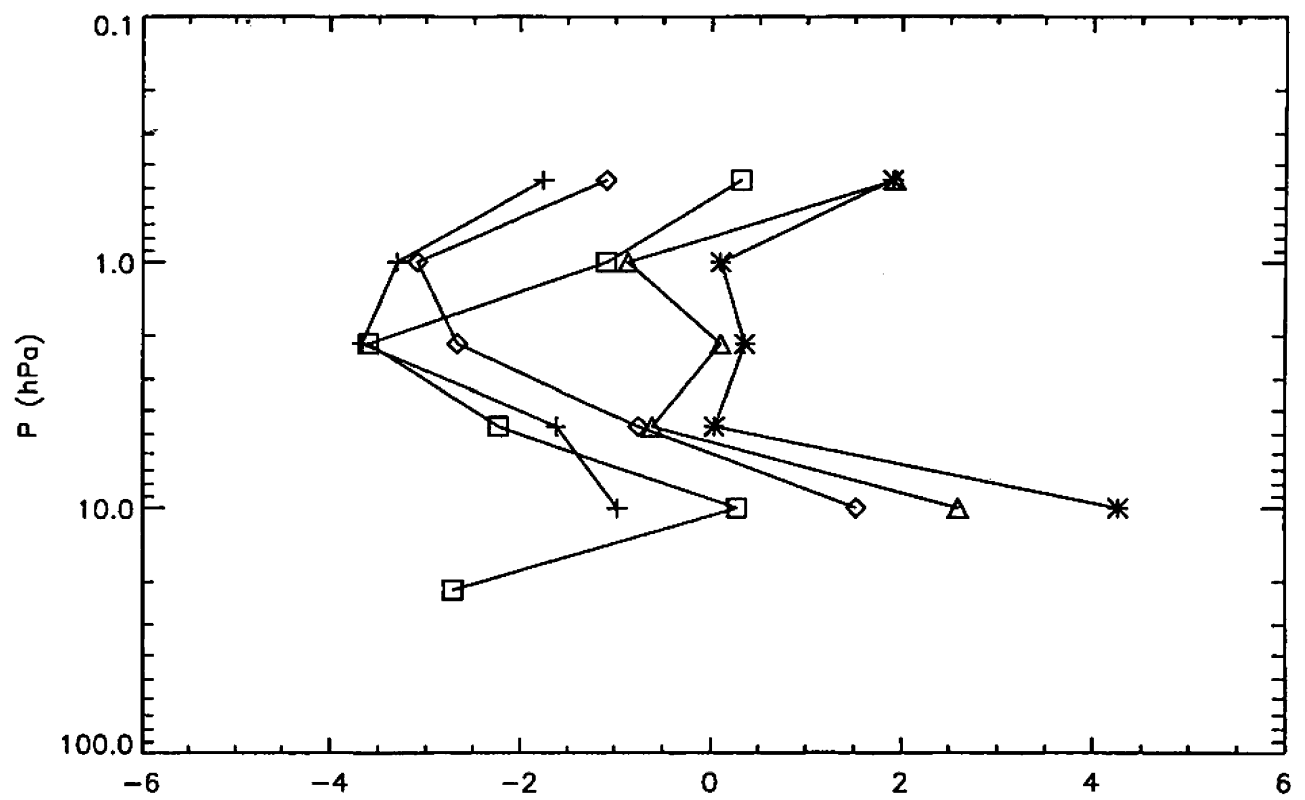

Fig. 4 Average differences between the closest MLS profile and the JPL lidar at TMF (plusses); the CNRS lidar at OHP (asterisks); the GSFC lidar at GSFC (diamonds), at TMF (triangles), and at OHP (squares) from Fishbein et al. ${ }^{54}$ (Copyright 1996, Journal of Geophysical Research). 


\section{Algorithm inter-comparisons}

Some instrument-related effects such as aerosol interferences, signal-induced-noise, and saturation of the data-acquisition system can degrade the quality of the lidar measurements. Several teams have addressed these problems and the expertise gained has been shared within the NDSC Lidar Working Group (LWG) and during inter-comparison exercises. Another possible instrumental effect not yet addressed was the filtering effects for ozone DIAL technique. All the teams involved in the NDSC use various low-pass filters, with variable cut-off frequencies with altitude, to account for the rapid decrease in the signal-to-noise ratio in the high altitude range. An intercomparison of the ozone DIAL lidar algorithms based on artificial signals was performed in 1996 (Fig. 5) within the framework of the NDSC lidar-working group. ${ }^{56}$ The results of the simulations showed that below $30 \mathrm{~km}$ all the retrieval algorithms observed the correct behavior with biases of less than $1 \%$. Above this altitude the bias increased, especially above $40 \mathrm{~km}$ where $10 \%$ biases were reported. This result questions the ability of the DIAL technique to retrieve the correct ozone profile at these altitudes. However, if the biases are constant over time they might be irrelevant for trend studies. This limit is due to the signal-to-noise ratio available. This comparison was an important contribution because it explained some differences observed in the upper stratosphere during the previous comparisons between lidar itself or with satellites.

The CNRS and GSFC algorithms used to retrieve temperature were compared using the same raw data file. This study revealed differences smaller than the noise $(<1.5 \mathrm{~K})$ up to $70 \mathrm{~km}$. Above this altitude the differences were larger and were probably related to the difference in methods for estimating and correcting for noise. Since then, the CNRS temperature software was recoded. The underlying physics remained unchanged but many functionalities were automated. At this time, the JPL algorithm was also evaluated and improved. The new CNRS version was tested and compared with the JPL version; ${ }^{17}$ showing no bias below $70 \mathrm{~km}$. The JPL and CNRS temperature algorithms have been tested using an alternative method that used artificial signals by Leblanc et al. ${ }^{17}$ It reveals errors smaller than $1 \mathrm{~K}$ below $60 \mathrm{~km}$ and $5 \%$ around $80 \mathrm{~km}$. Noise mainly due to counting uncertainties is expected to be smaller than $1 \mathrm{~K}$ below $60 \mathrm{~km}$ and around 5-20 K at $80 \mathrm{~km}$ depending on the filtering effects and resolution. If Raman scattering is used, then the profile can be obtained downward with a larger noise of several Kelvin. Investigation about the temperature retrieval based on Nitrogen Raman signals have been performed by Fadhuile et al. ${ }^{57}$ showing the importance of estimating ozone and aerosol attenuations with simultaneous ancillary measurements.

\section{Discussion and conclusions}

Many intercomparisons of ozone and temperature profiles have been performed under the framework of the NDSC. Since the instruments were designed independently, it offers a good opportunity to evaluate the overall capability of such instruments for atmospheric monitoring. While the use of a mobile instrument travelling from one station to another is the preferred method for comparisons, satellites can also provide a good spatial transfer for a quasi-simultaneous comparison of several lidars. This is particularly true for ozone in the mid and upper stratosphere where the atmosphere is in photochemical equilibrium. In the lower stratosphere the horizontal and temporal variability is mainly driven by the transport and large fluctuations can be observed for non-simultaneous and noncollocated comparisons. For temperature in the upper stratosphere and mesosphere, tidal effects cause systematic changes and can induce bias in the data comparisons when they are not performed simultaneously. Also for temperature, summertime is more appropriate for comparisons as the variability has a strong seasonal component at mid and high latitudes. Variability is smaller in the tropics and does not exhibit a strong seasonal cycle. During winter, at high latitude the permanent daylight restricts the use of lidars. Few systems have been designed for daylight operations. In the lower stratosphere the presence of aerosols required the development of more sophisticated methods to provide non-biased data for both ozone and temperature. However, these techniques have been developed more recently and the quality of the data provided in this altitude range has been investigated less. The comparisons conducted with the mobile lidar, as well as algorithm inter-comparisons, allow improvements to individual systems by sharing the knowledge of the different groups involved in the NDSC. While not all the instruments have participated in intercomparison campaigns, conclusions can be drawn from this review with respect to two important issues: (1) the overall quality and homogeneity of the NDSC lidar

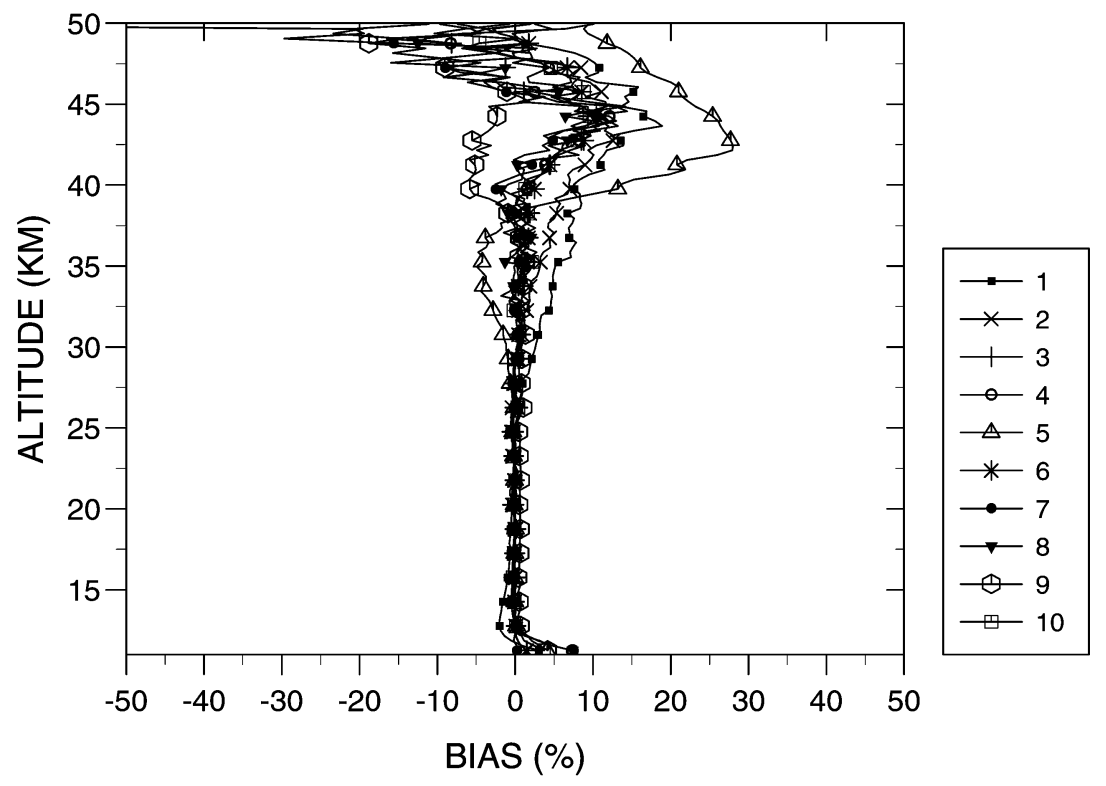

Fig. 5 Comparison of 10 analysis ozone retrieval softwares within NDSC from Godin et al. ${ }^{56}$ (Copyright 1999, Applied Optics). 
measurements, and (2) the capabilities of lidars to monitor long-term changes.

Through selection of the latest and/or best comparisons with the mobile lidar, the overall capabilities of the NDSC lidars have been determined (Table 3). For ozone, the standard deviations of the individual differences are comparable to the individual noise estimates. However, differences remain that are never smaller than $2 \%$ and are often around $5 \%$ in the altitude range from 25 to $35 \mathrm{~km}$. These types of differences were obtained for most of the sites where comparison campaigns with the mobile system were performed. Also, the best comparisons between lidars and SAGE II exhibit similar agreements. Larger biases are often observed at the top of the profile that are probably due to the effects of signal-induced noise and the different numerical filters used in the ozone analysis. In the lower stratosphere, filamentary structures, due to horizontal motions, induce a large spatio-temporal variability that requires perfect coincidences or a large number of individual comparisons.

For temperature, fewer comparison campaigns have been performed under conditions where tides have not masked instrumental differences. While the standard deviations of the individual differences were close to the estimated noise, biases of $1 \mathrm{~K}$ are reported. Larger biases are reported below $30-35 \mathrm{~km}$, due to stratospheric aerosols and around the top of the profile $75-85 \mathrm{~km}$ probably due to initialization and noise extraction. The use of satellite data is difficult for assessing temperature lidar measurements because tidal effects bias comparisons. To avoid such effects, solar occultation experiments would be preferred. However the number of coincidences would then be drastically reduced.

\section{Recommendations and future plans}

In conclusion, most of the lidars compared in the framework of NDSC can be now considered as operational and the lidar technique is quite mature for monitoring and satellite validation. For satellite validations, the network can, in principle, be considered as homogeneous within $\pm 2 \%$ between $20-35 \mathrm{~km}$ for ozone and $\pm 1 \mathrm{~K}$ between $35-60 \mathrm{~km}$ for temperature. However, more efforts are required for temperature comparisons. The valid altitude range, for a nominal accuracy associated to trend detection, is given below. In the lower stratosphere, Raman channels seem to improve comparisons, but such capabilities were not systematically compared, probably because they have been implemented only more recently. For both ozone and temperature systems this issue needs to be addressed. The top profiles need also to be considered with caution as bias increases quickly with altitude. For ozone, microwave spectrometers, already involved within NDSC, are ideal candidates to extend above around $40 \mathrm{~km}$, ozone measurements. For temperature powerful systems are required to push upward the initialization altitude, however signal-induced-noise can in turn bias the measurements. Special care is required. Tests and comparisons are likely to be performed but instrumental design is probably the most crucial part if covering the whole mesosphere is required.

Table 3 Errors (systematic and random) expected within ozone and temperature lidar within the NDSC

\begin{tabular}{llll}
\hline Parameter & Altitude & Bias & Variance \\
\hline Ozone & $<20 \mathrm{~km}$ & $5-10 \%$ without Raman channels & $5 \%$ \\
& $<20 \mathrm{~km}$ & $5 \%$ with Raman channels & $5 \%$ \\
& $20-35 \mathrm{~km}$ & $2 \%$ & $2 \%$ \\
& $>40 \mathrm{~km}$ & $5-10 \%$ & $5-10 \%$ \\
Temperature & $30 \mathrm{~km}$ & $5-10 \mathrm{~K}$ without a Raman channel & $2 \mathrm{~K}$ \\
& $30 \mathrm{~km}$ & Expected 1 K with a Raman & $4 \mathrm{~K}$ \\
& & channel & $2 \mathrm{~K}$ \\
& $35-65 \mathrm{~km}$ & $1 \mathrm{~K}$ & $5-10 \mathrm{~K}$
\end{tabular}

For trend detection, better accuracy can be expected as the bias in a single instrument can remain unchanged and therefore the derived trends are significant despite possible systematic differences with other instruments. However, temporal discontinuities of this order can be expected on decadal timescale and need to be tracked by any means because they may induce spurious trends larger than those expected; $5-10 \%$ per decade for ozone, and several Kelvin per decade for temperature. Only two sites were visited twice by the mobile lidar system. Conditions of comparisons and instrumental improvements performed on all the systems do not provide information about the temporal stability. In principle, satellite experiments cannot offer such temporal reference because of their lifetime or their potential drift. This last decade, space measurements have been tremendously improved. For ozone, SAGE II was a quite good reference and served as a good horizontal geographical transfer among the different lidar sites. Also, the long-term, continuous nature of SAGE II results allowed such comparisons to be made at many different times and locations. However, such exercises were never synchronized and may involve different retrieval versions of SAGE II or different periods that are not truly comparable (drift or malfunctioning). In the future such exercises may be planned, as it will allow every DIAL lidar to be compared at the same time. GOMOS onboard ENVISAT utilizes an auto-calibrated technique based on stellar occultations. This technique is very promising to ensure long term monitoring. Despite the fact that the quality of the measurements may differ depending on the star observed, it will provide a lot more data than the solar occultation technique (potentially better coincidences) and a quasi-constant time-of-day period for the spatial measurements. Most of the NDSC ozone lidars are involved in GOMOS validation ${ }^{58}$ and this will also offer a good opportunity to evaluate simultaneously the different lidars, despite the possible latitudinal bias or the start dependence. Assimilation efforts will also help to ensure the lidar network coherence and then will probably be considered as one of the best future solutions for frequent quality checks. This will be tested with the validation of experiments aboard ENVISAT. The use of satellites permits comparisons to be made with all the stations including those with difficult access such the Antarctic site.

For temperature, global measurements with GPS (Global Positioning Systems) will probably provide accurate measurements. However it will not cover the upper stratosphere and mesosphere. In this region tides cause some interferences that are not easy to handle since the amplitudes of the tides are also subject to strong variability. ${ }^{59}$ Satellite measurements based on solar occultation will provide good references. However, few good coincidences will be available at lower latitudes and comparisons of results will not be sufficiently accurate compared to the dynamical variability of the temperature at different timescales. Comparisons taking into account tides are not straightforward because tidal characteristics are not well known or measured. The attempts using some tidal climatology made in previous studies ${ }^{41,54}$ show some improvements but do not guarantee good representation of tides. Also, tide amplitudes can be modified in a complex manner ${ }^{59}$ related to changes in several atmospheric parameters (ozone content, water vapour content, temperature, wind) preventing the use of tide climatologies.

Since the temperature assimilation is a more difficult task, up to now, collocated intercomparison lidar campaigns and analysis methods are still needed in the near future. A special emphasis on the top part is required. Up to now, such campaigns, focused on temperature, were not sufficient to have a good view of the homogeneity of the network for the temperature. This is probably one of the main priorities in the next decade. Also, specific efforts on quality data evaluation obtained in the lower stratosphere domain need to be planned.

To be useful as a whole every lidar needs to be compared with a common reference in order to check if all their data quality fit the standard requirements that are expected from 
this study (Table 3). Also global validation plans need to be known to let every team, even outside the NDSC, to benefit the leadership provided by the network that could provide guidelines. The validation is proving difficult because differences can come both from the design and the analysis software. A common code will probably permit the raising of this issue and, at the same time, permit every team to reach the same degree of accuracy. About the design, this goal is virtually impossible to be predicted as lidar systems are sophisticated instruments that are often assembled through different phases. Also if the main body of the analysis is very similar within all the teams involved, the lidar technology itself is still improving. The analysis is not independent of the instrument itself and so is unique. However, one suggestion that can be made is the use of common software for all the analyses performed after signal corrections. This part of the analysis is not supposed to change much during the next decades. Then the design investigations can be shared to keep a certain degree of homogeneity in the network. However, this is not always easy to ensure as it strongly depends upon important resources.

\section{Appendix}

List of acronyms

\begin{tabular}{|c|c|}
\hline ALOMAR & $\begin{array}{l}\text { Artic Lidar Observatory for Middle Atmosphere } \\
\text { Research }\end{array}$ \\
\hline ARCLITE & ARCtic LIdar TEchnology \\
\hline AWI & Alfred Wegener Institute \\
\hline CLAES & Cryogenic Limb Array Etalon Spectrometer \\
\hline CMDL & Climate Monitoring and Diagnostic Laboratory \\
\hline CNR & Consiglio Nazionale delle Ricerche \\
\hline CNRS & Centre National de la Recherche Scientifique \\
\hline DDU & Dumont D’Urville \\
\hline DIAL & DIfferential Absorption Lidar \\
\hline ECC & Electrochemical Concentration Cells \\
\hline ENVISAT & ENVIronmental SATellite \\
\hline ERS-2 & European Remote Sensing Satellite \\
\hline GOME & Global Ozone Monitoring Experiment \\
\hline GOMOS & Global Ozone Monitoring by Occultation of Stars \\
\hline GPS & Global Positioning System \\
\hline GSFC & Goddard Space Flight Center \\
\hline HALOE & Halogen Occultation Experiment \\
\hline IFA & Istituto Fisica dell'Atmosfera \\
\hline ILAS & Improved Limb Atmospheric Spectrometer \\
\hline IROE & Istituto Recerche Onde Electromagnetica \\
\hline ISAMS & Improved Stratospheric and Mesospheric Sounder \\
\hline JPL & Jet Propulsion Laboratory \\
\hline MLO & Mauna Loa Observatory \\
\hline MLS & Microwave Limb Sounder \\
\hline $\mathrm{MOHH}$ & Meteorologisches Observatorium Hohenpeissenberg \\
\hline NAOMI & Ny-Ålesund Ozone Measurements Intercomparison \\
\hline NASA & National Administration and Space Agency \\
\hline NCEP & National Centers for Environmental Prediction \\
\hline NDSC & Network for Detection of Stratospheric Changes \\
\hline NIES & National Institute for Environmental Studies \\
\hline NILU & Norwegian Institue for Air Research \\
\hline NOAA & National Oceanic and Atmospheric Administration \\
\hline OHP & Observatory of Haute-Provence \\
\hline OPAL & Ozone Profiler Assessment at Lauder \\
\hline OTOIC & OHP temperature and Ozone Inter-Comparison \\
\hline POAM & Polar Ozone and Aerosol Measurement \\
\hline RIVM & Environmental Risks and External Safety Division \\
\hline ROCOZ & Rocket sondes, balloon ozonesondes \\
\hline SA & Service d'Aéronomie \\
\hline SABER & $\begin{array}{l}\text { Sounding of the Atmosphere using Broadband } \\
\text { Emission Radiometry }\end{array}$ \\
\hline SAGE & Stratospheric Aerosol and Gas Experiment \\
\hline SRI & \\
\hline STOIC & STratospheric Ozone Intercomparison Campaign \\
\hline STRAT & STRatosphere Aerosol comparisons at TMF \\
\hline SZA & Solar Zenith Angle \\
\hline TIMED & $\begin{array}{l}\text { Thermosphere, Ionosphere, Mesosphere, Energetics } \\
\text { and Dynamics spacecraft }\end{array}$ \\
\hline TMF & Table Mountain Facility \\
\hline UARS & Upper Atmosphere Research Satellite \\
\hline
\end{tabular}

\section{References}

1 M. J. Kurylo and S. Solomon, Network for the Detection of Stratospheric Change, NASA Report, Code EEU, 1990.

2 T. R. Karl, R. Q. Quayle and P. Y. Groisman, Detecting climate variations and change: New challenges for observing and data management systems, J. Clim., 1993, 6, 1481-1494.

3 G. Megie, J. Y. Allain, M. L. Chanin and J. E. Blamont, Vertical profile of stratospheric ozone $(18-28 \mathrm{~km})$ by lidar sounding from the ground, Nature, 1977, 270, 329.

4 T. J. McGee, M. R. Cross, R. Ferrare, W. Heaps and U. N. Singh, Raman DIAL measurements of stratospheric ozone in the presence of volcanic aerosols, Geophys. Res. Lett., 1993, 20, 955-958.

5 A. Hauchecorne and M.-L. Chanin, Density and temperature profiles obtained by lidar between 35 and $70 \mathrm{~km}$, Geophys. Res. Lett., 1980, 7, 565-568.

6 P. Keckhut, M. L. Chanin and A. Hauchecorne, Stratosphere temperature measurement using Raman lidar, Appl. Opt., 1990, 29, 5182-5186.

7 T. J. McGee, D. Witheman, R. Ferrare, J. J. Butler and J. Burris, STROZ LITE: Stratospheric Ozone Lidar Trailer Experiment, Opt. Eng., 1991, 30, 31-39.

8 T. J. McGee, M. R. Cross, U. N. Singh, J. J. Butler and P. E. Kimvilakani, Improved stratospheric ozone lidar, Opt. Eng., 1995, 34, 1421-1430.

9 T. J. McGee, P. Newman, M. Gross, U. Singh, S. Godin, S. Lacoste and G. Megie, Correlation of ozone loss with the presence of volcanic aerosols, Geophys. Res. Lett., 1994, 21, 2,8012,801 .

10 M. R. Gross, T. J. McGee, R. A. Ferrare, U. Singh and P. Kimvilikani, Temperature Measurements Made with a Combined Rayleigh-Mie/Raman Lidar, Appl. Opt., 1997, 24, 5987-5995.

11 S. Godin, G. Megie and J. Pelon, Systematic lidar measurements of the stratospheric ozone vertical distribution, Geophys. Res. Lett., 1989, 16, 547-550.

12 P. Keckhut, A. Hauchecorne and M. L. Chanin, A critical review of the data base acquired for the long term surveillance of the middle atmosphere by the French Rayleigh lidars, J. Atmos. Ocean. Technol., 1993, 10, 850-867.

13 J. Werner, K. W. Rothe and H. Walther, Monitoring of the stratospheric ozone layer by laser radar, Appl. Phys., 1983, B32, 113-118.

14 W. Steinbrecht, K. W. Rothe and H. Walther, Lidar setup for daytime and nighttime probing of stratospheric ozone and measurements in polar and equatorial regions, Appl. Opt., 1989, 28, 3616-3624.

15 C. B. Park, K. H. Park and C. H. Lee, Lidar observation of ozone and aerosol in the stratosphere and troposphere over Suwon, Korea, Advances in Atmospheric Remote Sensing with Lidar, Springer, New York-Berlin-Heidelberg, pp. 545-548, 1996.

16 I. S. McDermid, S. Godin and L. O. Lindquist, Ground-based laser DIAL system for long-term measurements of stratospheric ozone, Appl. Opt., 1990, 29, 3603-3612.

17 T. Leblanc, I. S. McDermid, A. Hauchecorne and P. Keckhut, Evaluation of optimization of lidar temperature analysis algorithms using simulated data, J. Geophys. Res., 1998, 103, 61776187.

18 E. J. Brinksma, Validation of 3 years of ozone measurements over Network for the Detection of Stratospheric Change station Lauder, New Zealand, J. Geophys. Res., 2000, 105, 17291-17306.

19 J-L. Baray, J. Leveau, J. Porteneuve, G. Ancellet, P. Keckhut, F. Posny and S. Baldy, Description and evaluation of a tropospheric ozone lidar implemented on an existing lidar in the southern subtropics, Appl. Opt., 1999, 38, 6808-6817.

20 D. P. Donovan, J. C. Bird, J. A. Whiteway, T. J. Duck, S. R. Pal and A. I. Carswell, Lidar observations of stratospheric ozone and aerosol, Geophys. Res. Lett., 1995, 22, 3489-3492.

21 F. Marenco, A. di Sarra, M. Cacciani, G. Fiocco and D. Fua, Thermal structure of the winter middle atmosphere observed by lidar at Thule, Greenland, during 1993-1994, J. Atmos. Sol. Terr. Phys., 1997, 59, 151-158.

22 J. P. Thayer, N. B. Nielsen, R. Warren, C. J. Heinselman and J. Sohn, Rayleigh lidar system for middle atmosphere research in the arctic, Opt. Eng., 1997, 36, 2045-2061.

23 A. J. Gerrard, T. J. Kane, J. P. Thayer, T. J. Duck and J. Whiteway, Synoptic-scale study of the arctic polar vortex's influence on the middle atmosphere, J. Geophys. Res., 2002, 107, pp. ACL1 1-15.

24 E. V. Thrane and U. von Zahn, ALOMAR - A new facility for 
middle atmosphere research at Arctic latitudes, J. Geomagn Geoelectr., 1995, 47, 921-928.

25 U.-P. Hoppe, G. Hansen and D. Opsvik, Differential absorption lidar measurements of stratospheric ozone at ALOMAR: First results, ESA SP-370, 1995, 335-344.

26 G. P. Gobbi, T. Deshler, A. Adriani and D. J. Hofmann, Evidence of denitrification in the 1990 Antarctic spring stratosphere 1. lidar and temperature measurements, Geophys. Res. Lett., 1991, 18 1995-1998.

27 A. Adriani, T. Deshler, G. Gobbi, B. Johnson and G. Di Donfrancesco, Polar stratospheric clouds over McMurdo, Antarctica, during the 1991 spring: lidar and particle counter measurements, Geophys. Res. Lett., 1991, 19, 1755-1758.

28 I. S. McDermid, S. M. Godin, L. O. Lindquist, T. D. Walsh, J. Burris, J. Butler, R. Ferrare, D. Whiteman and T. J. McGee, Measurement Inter-Comparison of the JPL and GSFC Stratospheric Ozone Lidar Systems, Appl. Opt., 1990, 29, 4671-4676.

29 I. S. McDermid, S. M. Godin and T. D. Walsh, Lidar Measurements of Stratospheric Ozone and Inter-Comparisons and Validation, Appl. Opt., 1990, 29, 4914-4923.

30 W. D. Komhyr, B. J. Connor, I. S. McDermid, T. J. McGee, A. D. Parrish and J. J. Margitan, Comparison of STOIC 1989 Ground-Based Lidar, Microwave Radiometer, and Dobson Spectrophotometer Umkehr Ozone Profiles With Ozone Profiles from Balloon-Borne ECC Ozonesondes, J. Geophys. Res., 1995, 100, 9273-9282.

31 J. J. Margitan, R. A. Barnes, G. B. Brothers, J. Butler, J. Burris, B. J. Connor, R. A. Ferrare, J. B. Kerr, W. D. Komhyr, M. P. McCormick, I. S. McDermid, C. T. McElroy, T. J. McGee, A. J. Miller, M. Owens, A. D. Parrish, C. L. Parsons, A. L. Torres, J. J. Tsou, T. D. Walsh and D. Whiteman, Stratospheric Ozone Intercomparison Campaign (STOIC) 1989: Overview, J. Geophys Res., 1995, 100, 9193-9208.

32 I. S. McDermid, S. M. Godin and T. D. Walsh, Results from the JPL Stratospheric Ozone Lidar During STOIC 1989, J. Geophys. Res., 1995, 100, 9263-9272.

33 G. O. Braathen, T. J. McGee, M. R. Gross, S. Godin, P. Keckhut, C. Vialle and A. Hauchecorne, Intercomparaison of stratospheric ozone and temperature measurements at the Observatoire de Haute Provence during an NDSC validation campaign from 1-18 July 1997, Geophys. Res. Lett., 2002, submitted.

34 I. S. McDermid, J. B. Bergwerff, G. Bodeker, I. S. Boyd, E. J. Brinksma, B. J. Connor, R. Farmer, M. R. Gross, P. Kimvilakani, W. A. Matthews, T. J. McGee, F. T. Ormel, A. Parrish, U. Singh, D. P. J. Swart, J. J. Tsou, P-H. Wang and J. Zawodny, OPAL: Network for the Detection of Stratospheric Change Ozone Profiler Assessment at Lauder, New Zealand. I. Blind Intercomparisons, J. Geophys. Res., 1998, 103, 28,68328,692 .

35 I. S. McDermid, J. B. Bergwerff, G. Bodeker, I. S. Boyd, E. J. Brinksma, B. J. Connor, R. Farmer, M. R. Gross, P. Kimvilakani, W. A. Matthews, T. J. McGee, F. T. Ormel, A. Parrish, U. Singh, D. P. J. Swart and J. J. Tsou, OPAL: Network for the Detection of Stratospheric Change Ozone Profiler Assessment at Lauder, New Zealand. II. Intercomparison of Revised Results, J. Geophys. Res., 1998, 103, 28,693-28,699.

36 I. S. Boyd, G. E. Bodeker, B. J. Connor, D. P. J. Swart and E. J. Brinksma, An assessment of ECC ozonesondes operated using $1 \%$ and $0.5 \% \mathrm{Kl}$ cathode solutions at Lauder, New Zealand, Geophys. Res. Lett., 1998, 25, 2409-2412.

37 I. S. McDermid, T. J. McGee, D. P. J. Swart, NDSC Lidar Intercomparisons and Validation: OPAL and MLO3 Campaigns in 1995, Advances in Atmospheric Remote Sensing with Lidar, Springer, New York-Berlin-Heidelberg, 1996, pp. 525-528.

38 R. D. McPeters, D. J. Hofmann, M. Clark, L. Flynn, L. Froidevaux, M. Gross, B. Johnson, G. Koenig, X. Liu, I. S. McDermid, T. J. McGee, F. Murcray, M. J. Newchurch, S. Oltmans, A. Parrish, R. Schnell, U. Singh, J. J. Tsou, T. D. Walsh and J. M. Zawodny, Results from the 1995 Stratospheric Ozone Profile Intercomparison at Mauna Loa, J. Geophys. Res., 1999, 104, 30,505-30,514.

39 W. Steinbrecht, M. R. Gross, T. J. McGee, R. Neuber, P. von der Gathen, P. Wahl, U. Klein and J. Langer, Results of the 1998 NyÅlesund Ozone Measurements Intercomparison NAOMI, J. Geophys. Res., 1999, 104, 30,515-30,523.

40 U. N. Singh, P. Keckhut, T. J. McGee, M. R. Gross, A. Hauchecorne, E. F. Fishbein, J. W. Waters, J. C. Gille, A. E. Roche and J. M. Russell III, Stratospheric temperature measurements by two collocated NDSC lidars at OHP during UARS validation campaign, J. Geophys. Res., 1996, 101, 1028710297.
41 P. Keckhut, J. Wild, M. Gelman, A. J. Miller and A. Hauchecorne, Investigations on long-term temperature changes in the upper stratosphere using lidar data and NCEP analyses, J. Geophys. Res., 2001, 106, 7937-7944.

42 J. D. Wild, M. E. Gelman, A. J. Miller, M. L. Chanin, A. Hauchecorne, P. Keckhut, R. Farley, P. D. Dao, J. W. Meriwether, G. P. Gobbi, F. Congeduti, A. Adriani, I. S. McDermid, T. J. McGee and E. F. Fishbein, Comparison of stratospheric temperatures from several lidars, using National Meteorological Center and microwave limb sounder data as transfer references, J. Geophys. Res., 1995, 100, 11,105-11,111.

43 I. S. McDermid, S. M. Godin, P-H. Wang and M. P. McCormick, Comparison of Stratospheric Ozone Profiles and Their Seasonal Variations as Measured by LIDAR and SAGE II During 1988, J. Geophys. Res., 1990, 95, 5605-5612.

44 J. J. Tsou, B. J. Connor, A. Parrish, I. S. McDermid and W. P. Chu, Ground-Based Microwave Monitoring of Middle Atmosphere Ozone: Comparison to Lidar and SAGE II Satellite Observations, J. Geophys. Res., 1995, 100, 3005-3016.

45 H. Nakane, Y. Sasano, S. S. Hayashida, N. Sugimoto, I. Matsui, A. Minato and M. P. McCormick, Comparison of ozone profiles obtained with NIES DIAL and SAGE II measurements, J. Meteorol. Soc. Jpn, 1993, 71, 153-159.

46 C. Bruhl, S. R. Drayson, J. M. Russell, P. J. Crutzen, J. M. McInerney, P. N. Purcell, H. Claude, H. Gernandt, T. J. McGee and I. S. McDermid, Halogen Occultation Experiment ozone channel validation, J. Geophys. Res., 1996, 101, 10,217-10,240

47 P. L. Baily, D. P. Edwards, J. C. Gille, L. V. Lyjak, S. T. Massie, A. E. Roche, J. B. Kumer, J. L. Mergenthaler, B. J. Connor, M. R. Gunson, J. J. Margitan, I. S. McDermid and T. J. McGee, Comparison of cryogenic limb array etalon spectrometer (CLAES) ozone observations with correlative measurements, J. Geophys. Res., 1996, 101, 9737-9756.

48 L. Froidevaux, W. G. Read, T. A. Lungu, R. E. Cofield, E. F. Fishbein, D. A. Flower, R. F. Jarnot, B. P. Ridenoure, Z. Shippony, J. W. Waters, J. J. Margitan, I. S. McDermid, R. A. Stachnik, G. E. Peckham, G. Braathen, T. Deshler, J. Fishman, D. J. Hofmann and S. J. Oltmans, Validation of UARS Microwave Limb Sounder ozone measurements, J. Geophys. Res., 1996, 101, 10,017-10,060.

49 J. P. Burrows, M. Weber, M. Buchwitz, V. Romanov, A. Ladstätter-Weißenmayer, A. Richter, R. Debeek, R. Hoogen, K. Bramstedt, K.-U. Eichmann, M. Eisinger and D. Perner, The Global Ozone Monitoring Experiment (GOME): Mission concept and first scientific results, J. Atmos. Sci., 1999, 56, 151-175.

50 Y. J. Meijer, R. J. van der A, R. F. van Oss, D. P. J. Swart, H. M. Kelder and P. V. Johnston, GOME ozone profile characterization using interpretation tools and lidar measurements for intercomparison, J. Geophys. Res., 2003, submitted

51 S. P. Namboothiri, N. Sugimoto, H. Nakane, I. Matsui and Y. Murayama, Rayleigh lidar observation of temperature over Tsukuba: winter thermal structure and comparison studies, Earth Planets and Space, 1999, 51, 825-832.

52 M. E. Hervig, J. M. Russell III, L. L. Gordley, S. R. Drayson, K. Stone, R. E. Thompson, M. E. Gelman, I. S. McDermid, A. Hauchecorne, P. Keckhut, T. J. McGee, U. N. Singh and M. R. Gross, Validation of temperature measurements from the Halogen Occultation Experiment, J. Geophys. Res., 1996, 101, $10277-10285$

53 J. C. Gille, P. L. Bailey, S. T. Massie, L. V. Lyjak, D. P. Edwards, A. E. Roche, J. B. Kumer, J. L. Mergenthaler, M. R. Gross, A. Hauchecorne, P. Keckhut, T. J. McGee, I. S. McDermid, A. J. Miller and U. Singh, Accuracy and precision of Cryogenic Limb Array Etalon Spectrometer (CLAES) temperature retrievals, J. Geophys. Res., 1996, 101, 9583-9601.

54 E. F. Fishbein, R. E. Cofield, L. Froidevaux, R. F. Jarnot, T. Lungu, W. G. Read, Z. Shippony, J. W. Waters, I. S. McDermid, T. J. McGee, U. N. Singh, M. Gross, A. Hauchecorne, P. Keckhut, M. E. Gelman and R. M. Nagatani, Validation of UARS Microwave Limb Sounder temperature and pressure measurements, J. Geophys. Res., 1996, 101, 9983-10016.

55 P. Keckhut, M. E. Gelman, J. D. Wild, F. Tissot, A. J. Miller, A. Hauchecorne, M. L. Chanin, E. F. Fishbein, J. Gille, J. M. Russell III and F. W. Taylor, Semidiurnal and diurnal temperature tides $(30-55 \mathrm{~km})$ : climatology and effect on UARSLIDAR data comparisons, J. Geophys. Res., 1996, 101, 1029910310.

56 S. Godin, A. I. Carswell, D. P. Donovan, H. Claude, W. Steinbrecht, I. S. McDermid, T. J. McGee, M. R. Gross, H. Nakane, D. P. J. Swart, H. B. Bergwerff, O. Uchino, P. von der 
Gathen and R. Neuber, Ozone differential absorption lidar algorithm intercomparison, Appl. Opt., 1999, 38, 6225-6236.

57 D. Faduilhe, P. Keckhut, H. Bencherif, B. Cadet and S. Baldy, personal communication.

58 P. Keckhut, S. Marchand, A. Hauchecorne, S. Godin-Beekmann, F. Pinsard, I. S. McDermid, T. Leblanc, G. Hansen, J.-L. Baray, H. Bencherif, D. Swart, Y. Meijer, S. Pal, M. Guirlet, C. Vialle, F. Posny and F. Goutail, Validation of GOMOS ozone profiles using NDSC lidar: statistical comparisons, Proceedings of ENVISAT Validation Workshop, ESA Publications Division, SP-531, ed. H. Lacoste, 2003.

59 B. Morel, P. Keckhut, H. Bencherif, A. Hauchecorne, G. Megie and S. Baldy, Investigation of the tidal variations in a 3-d dynamics-chemistry-transport model of the middle atmosphere, J. Atmos. Sol. Terr. Phys., 2004, 66, 251-265. 